\title{
Mussel beds - amensalism or amelioration for intertidal fauna?
}

\author{
Sabine Dittmann*
II. Zoologisches Institut der Universität Göttingen; Berliner Str. 28, D-W-3400 Göttingen, Germany
and \\ Biologische Anstalt Helgoland, Wadden Sea Station List, D-W-2282 List/Sylt, Germany
}

\begin{abstract}
The faunal assemblages of a mussel bed (Mytilus edulis L.) and ambient sandflat were compared to study how a bioherm of suspension feeding organisms affects benthic communities in a tidal flat. During a survey of mussel beds in the Wadden Sea at the island of Sylt (North Sea), a total of 52 macrofaunal species and 44 meiobenthic plathelminth species were detected. They occupied different microhabitats in the mussel bed. $56 \%$ of the macrofauna species were dwelling in the sediment beneath the mussels and $42 \%$ were epibenthic or epiphytic. The latter were restricted in their occurrence to the mussel bed. Along a transect from the sandflat to the mussel bed the mean species densities of macrofauna did not differ significantly, while abundances were significantly lower in the mussel bed than in the sandflat. The composition of the assemblages shifted from a dominance of Polychaeta in the sandflat to Oligochaeta in the mussel bed. Surface filter-feeding polychaetes of the sandflat (Tharyx marioni) were displaced by deposit feeding polychaetes under the mussel cover (Capitella capitata, Heteromastus filiformis). The total meiobenthic density was lower and single taxa (Ostracoda, Plathelminthes, Nematoda) were significantly less abundant in the mud of the mussel bed. The plathelminth assemblage was dominated by grazing species (Archaphanostoma agile), and differed in community structure from a sandflat assemblage. An amensalistic relationship was found between the suspension-feeding mussels and suspensionfeeding infauna, while deposit-feeders were enhanced. The presence of epibenthic microhabitats results in a variety of trophic groups co-occurring in a mussel bed. This is hypothesized as trophic group amelioration and described as an attribute of heterotrophic reefs.
\end{abstract}

\section{INTRODUCTION}

Discrete distribution patterns of functionally different organisms in soft sediments have been explained by functional-group hypotheses. The mutual exclusion of trophic groups has been attributed to trophic group amensalism (Rhoads \& Young, 1970). Sediment modifications by deposit-feeders interfere with the requirements of suspension-feeders and cause them to settle in separate areas. Woodin (1976) hypothesized adult-larval interactions as the mechanisms to maintain discrete assemblages. She predicts that no infaunal forms should attain high densities among dense suspensionfeeding bivalves. This was rejected by Commito (1987) and Commito \& Boncavage (1989) who found high infaunal densities inside mussel beds and suggested a modification of Woodin's hypothesis by excluding infauna with benthic development stages.

\footnotetext{
- Present address: Australian Institute of Marine Science PMB No. 3, Townsville M.C. Q 4810, Australia
} 
Mussel beds are dense assemblages of suspension-feeders. In the Wadden Sea, the biomass values of intertidal mussel beds are among the highest for benthic communities (Asmus, 1987; Beukema, 1976), and they are an important component of the production of the Wadden Sea. However, the role of mussel beds as a habitat for intertidal organisms has never been completely investigated. On rocky substrates they increase habitat heterogeneity and are inhabited by a species rich and diverse fauna (Tsuchiya \& Nishihira, 1985, 1986; Suchanek, 1980). Species diversity of fauna in the sediment accumulating under mussel cultures decreases in comparison with adjacent mussel-free areas and shifts in trophic structure to a domination of deposit-feeders (Mattson \& Linden, 1983; Roman \& Perez, 1982; Rosenberg \& Loo, 1983; Tenore \& Gonzales, 1976). This study evaluates the impact of mussel beds on endobenthic and epibenthic organisms in a tidal flat. Differences in community organisation inside and outside the mussel beds are addressed. Results from experimental investigations on the colonization of newly created mussel aggregates and biodeposit enriched patches are in preparation.

\section{MATERIAL AND METHODS}

Mussel beds in the northern part of the Wadden Sea near the island of Sylt $\left(55^{\circ} 2^{\prime} \mathrm{N}\right.$, $8^{\circ} 26^{\prime} E$ ) were surveyed from 1982 to $1986.8 .80 \%$ of the area of the sheltered tidal bay of Königshafen were covered by beds of Mytilus edulis L. (Asmus, 1987) (Fig. 1). Their existence has been reported since the beginning of this century (Hagmeier \& Kändler, 1927; Wohlenberg, 1937). Fluctuations in the size of these mussel beds have been due to severe winters (Ziegelmeier, 1964, 1970) and human perturbations (Riesen \& Reise, 1982). Severe winters and commercial mussel fishery destroyed the mussel beds in 1986 and 1987.

Mussel beds in the Königshafen vary in their structure (size, single or coherent beds with or without tide pools), their sediment texture (content of shell debris), and the presence or absence of epifauna (mainly barnacle cover and grazing snails) (Dittmann, 1987). The mean density of mussels was $1301 \pm 459$ individuals $\mathrm{m}^{-2}(\mathrm{n}=24)$. The accumulation of biodeposits by the mussels amounts to $125 \mathrm{l} \mathrm{m}^{-2} \mathrm{yr}^{-1}$, which is equivalent to an annual input of organic matter of $4 \mathrm{~kg} \mathrm{~m}^{-2}$ (Dittmann, 1987). Physical characteristics of the sandflat and mussel bed are given in Table 1.

Species associated with mussel beds were recorded during observations, experiments and benthic surveys. To compare faunal assemblages from sandflat and mussel bed, a transect was laid in the inner part of the bay (Fig. 1). Three stations were sampled: the sandflat ( $2 \mathrm{~m}$ outside of the mussel bed), the edge and the centre of the mussel bed ( $2 \mathrm{~m}$ inside). These stations were sampled on September 15, 1984; March 21 and May 1 , 1985.

Macrofaunal samples ( $\mathrm{n}=6$ for each station and date) were taken with a box corer of $100 \mathrm{~cm}^{2}$ surface area down to a depth of 10 to $15 \mathrm{~cm}$. In the mussel bed the cores had to be dug out of the mud. The sediment was sieved through a gauze of $0.5 \mathrm{~mm}$ mesh size. On the last two sampling dates the horizon of $0-2 \mathrm{~cm}$ depth was separately sieved through $0.25 \mathrm{~mm}$ mesh size. Residues from the sieves were washed into sorting dishes from where living macrofauna were extracted. Specimens were counted under a dissecting microscope. Polychaetes, molluscs and crustaceans were identified to species level. Oligochaetes were not determined to species. 


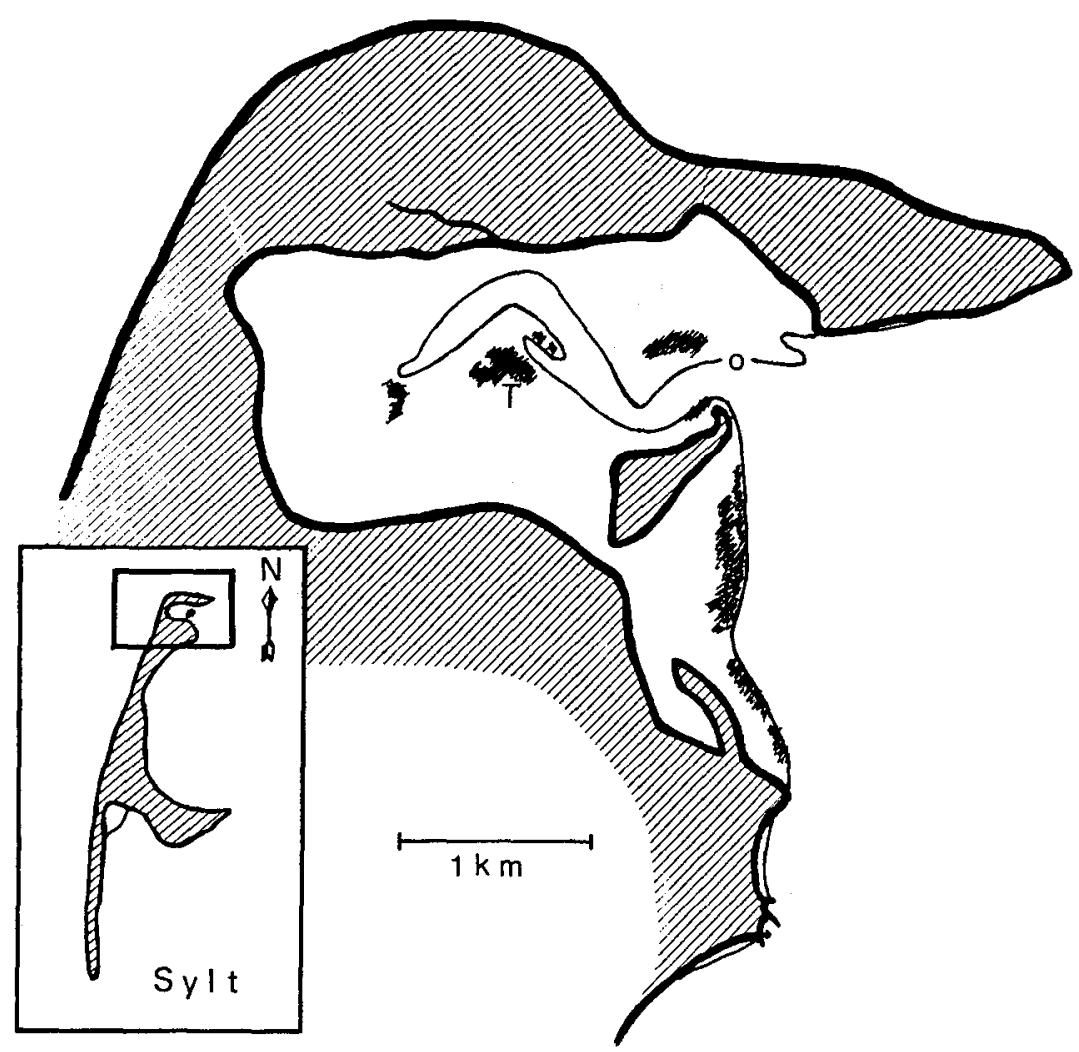

Fig. 1. The tidal flat area of the Königshafen at the island of Sylt (North Sea). Mussel beds above the mean low water line (-0-) are shaded. Their expansion is reported for the period of investigation from 1982 to 1986 . $T$ indicates the location of the transect

Table 1. Physical characteristics of tidal flat areas in the Königshafen at the island of Sylt (North Sea), taken from Reise (1983) and Dittmann \& Reise (1985)

\begin{tabular}{|lcc|}
\hline Parameter & Sandflat & Mussel bed \\
\hline Depth at high tide (cm) & 160 & 170 \\
Average duration of exposure (h) & 2 & 2 \\
Salinity (\%) & $28-32$ & $28-32$ \\
Median grain size (mm) & 0.46 & 0.8 \\
Water content of sediment at low tide (\%) & - & 45 \\
Organic matter (loss of ignition in \% d.w.) & 0.40 & 5.10 \\
\hline
\end{tabular}

Meiofaunal samples $(n=6$ each) were taken at the sandflat and centre station of the transect on September 29, 1984, with a corer of $1 \mathrm{~cm}^{2}$ surface area to a depth of $2 \mathrm{~cm}$. Meiofauna were extracted by diluting the sediment with filtered seawater and repeated shaking and decanting of the supernatant through a set of sieves with $0.125-0.08$ and 
$0.04 \mathrm{~mm}$ mesh size. Samples were neither narcotized nor stained. Meiofauna were counted using a dissecting microscope. Plathelminthes were identified to species at higher microscopic magnification.

The meiofauna comprised $0.2-10 \%$ Plathelminthes, varying between mussel beds. Their assemblage was surveyed in 1982/83 (November, February, May) (Dittmann, 1984). 40 samples were taken each month with a syringe of $2.2 \mathrm{~cm}^{2}$ diameter to $1.5 \mathrm{~cm}$ depth. The mud was covered with azoic sand and soaked with seawater (Armonies \& Hellwig, 1986). The animals migrated into the sand following an oxygen gradient and could be extracted within one to three days as described above.

Differences in faunal densities between sampling sites were tested with the nonparametric U-test of Wilcoxon, Mann \& Whitney (Sachs, 1984). A difference was considered significant if $P \leq 0.05$. The mean densities $(x)$ and standard deviations (s) of replicate samples are given. Similarity between stations was compared with Sørensen's index QS (Sørensen, 1948), testing for common species, and Renkonen's index R (Renkonen, 1938), testing the dominance structure of species common to both sites.

\section{RESULTS}

\section{Species survey}

96 invertebrate species were associated with the intertidal mussel beds of the Königshafen (Table 2). Species were distributed within the following microhabitats: 71 species occurred in the sediment beneath the mussel layer; 27 species were recorded as epifauna, primarily on the mussels ( 13 species), or secondarily on sponges, hydrozoans or algae associated with the mussels (17 species). Three of the later category were also found primarily on mussels (Littorina littorea, Harmothoe impar, Polydora ciliata). Five species were either endobenthic or epibenthic on the mussel bed (Promesostoma gracilis, $P$. karlingi, P. rostratum, Eumida sanguinea, Polydora ciliata). Three species occurred on mussel beds as low tide or high tide guests, as did species of fish and birds not included in the present investigation.

\section{Comparison between macrofaunal assemblages of mussel bed and sandflat}

The mean species density over all stations, irrespective of microhabitat, was 10 species $100 \mathrm{~cm}^{-2}$ (Table 3). The number of species was higher in the mussel bed due to the occurrence of epibenthic and epiphytic species (mainly crustaceans and molluscs, see Table 2). $56 \%$ of the macrofauna species were found in the sediment and $42 \%$ on the mussels. The species density of endobenthic Polychaeta was significantly higher $(P \leq 0.001)$ in the sandflat.

The mean individual density of the total macrofauna declined along the transect with abundances being lower in the mussel bed $\left(125 \pm 97\right.$ individuals $\left.100 \mathrm{~cm}^{-2}\right)$ than in the sandflat $\left(173 \pm 62\right.$ individuals $\left.100 \mathrm{~cm}^{-2}\right)(\mathrm{P} \leq 0.05)$ (Fig. 3). The composition of macrofauna shifted from Polychaeta dominating in the sandflat ( $83 \%$ of all individuals) to Oligochaeta ( $61 \%$ of the total) in the mussel bed (Fig. 2). At the edge of the mussel bed they occurred in almost equal proportions of the macrofauna. Rare polychaete species (mean abundance $<1$ individual $100 \mathrm{~cm}^{-2}$ ) were found frequently in the sandflat, but not 
Table 2. Species recorded between 1982 and 1986 on intertidal mussel beds of the Königshafen (Isle of Sylt, North Sea). According to their occurrence in microhabitats they are recorded as endofauna or epifauna, with $\mathrm{M}=$ epifauna on mussels, $\mathrm{A}=$ epifauna on algae (Fucus vesiculosus), $\mathrm{S}=$ epifauna on sponges (Halichondria panicea) and $\mathrm{H}=$ epifauna on hydrozoans (Laomedea sp.)

\begin{tabular}{|c|c|c|c|}
\hline TAXA & Endofauna & Epifauna & Guest \\
\hline \multicolumn{4}{|l|}{ PORIFERA } \\
\hline Halichondria panicea (Pallas) & & A & \\
\hline \multicolumn{4}{|l|}{ ANTHOZOA } \\
\hline Metridium senile L. & & M & \\
\hline \multicolumn{4}{|l|}{ PLATHELMINTHES } \\
\hline Pseudostomum brevicaudatum Dörjes 1968 & + & & \\
\hline Pseudaphanostoma pelophilum Dörjes 1968 & + & & \\
\hline Pseudaphanostoma psammophilum Dörjes 1968 & + & & \\
\hline Archaphanostoma agile (Jensen 1878) & + & & \\
\hline Anaperus tvaerminnensis (Luther 1912) & + & & \\
\hline Philachoerus johanni Dörjes 1968 & + & & \\
\hline Philactinoposthia saliens (Graff 1882) & + & & \\
\hline Mecynostomum auritum (Schultze 1851) & + & & \\
\hline Archimonotresis limophila Meixner 1938 & + & & \\
\hline Pseudostomum quadrioculatum (Leuck 1847) & & $\mathrm{H}$ & \\
\hline Macrostomum pusillum $\mathrm{Ax} 1951$ & + & & \\
\hline Microstomum papillosum Graff 1882 & + & & \\
\hline Microstomum bioculatum Faubel 1984 & + & & \\
\hline Archilopsis unipunctata Fabricius 1928 & + & & \\
\hline Promonotus schultzei Meixner 1943 & + & & \\
\hline Monocoelis fusca Oersted 1843 & + & & \\
\hline Pratoplana salsa Ax 1960 & + & & \\
\hline Promesostoma gracilis Ax 1951 & + & $\mathrm{H}$ & \\
\hline Promesostoma karlingi Ehlers 1974 & + & $\mathrm{H}$ & \\
\hline Promesostoma rostratum Ax 1951 & + & $\mathrm{H}$ & \\
\hline Promesostoma meixneri Ax 1951 & + & & \\
\hline Promesostoma marmoratum (M. Schultze 1851) & + & & \\
\hline Promesostoma caligulatum Ax 1952 & + & & \\
\hline Ptychoptera westbladi Luther 1943 & + & & \\
\hline Ptychoptera hartogi Ax 1971 & + & & \\
\hline Proxenetes quinquespinosus Ax 1951 & + & & \\
\hline Proxenetes quadrespinosus Den Hartog 1966 & + & & \\
\hline Proxenetes intermedius Den Hartog 1966 & + & & \\
\hline Proxenetes segmentatus Den Hartog 1966 & + & & \\
\hline Proxenetes ampullatus Ax 1971 & + & & \\
\hline Breslauilla relicta Reisinger 1929 & + & & \\
\hline Halammovortex macropharynx Meixner 1938 & + & & \\
\hline Pogaina suecica (Luther 1948) & + & & \\
\hline Pseudografilla arenicola Meixner 1938 & + & & \\
\hline Acrorhynchides robustus Karling 1931 & + & & \\
\hline Gyratrix hermaphroditus Ehrenberg 1831 & + & & \\
\hline Scanorhynchus forcipatus Karling 1955 & + & & \\
\hline Phonorhynchus helgolandicus (Mezcnik.) & & $\mathrm{H}$ & \\
\hline Zonorhynchus seminascatus Karling 1956 & + & & \\
\hline Placorhynchus octaculeatus (Karling 1947) & + & & \\
\hline Psittacorhynchus verweyi Den Hartog 1968 & + & & \\
\hline
\end{tabular}


Table 2 (continued)

\begin{tabular}{|c|c|c|c|}
\hline TAXA & Endofauna & Epifauna & Guest \\
\hline \multicolumn{4}{|l|}{ PLATHELMINTHES } \\
\hline Schizorhynchoides spirostylus Boaden 1963 & + & & \\
\hline Schizorhynchoides indet. & + & & \\
\hline Rhinepera remanei Meixner 1928 & + & & \\
\hline \multicolumn{4}{|l|}{ NEMERTINI } \\
\hline Lineus viridis (Müller) & + & & \\
\hline Amphiporus lactifloreus (Johnston) & + & & \\
\hline Cephalotrix linearis (Rathke) & + & & \\
\hline \multicolumn{4}{|l|}{ ECHIURIDA } \\
\hline Echiurus echiurus (Pallas) & + & & \\
\hline \multicolumn{4}{|l|}{ MOLLUSCA } \\
\hline Littorina littorea L. & & $\mathrm{M}, \mathrm{A}$ & \\
\hline Littorina obtusata L. & & A & \\
\hline Hydrobia ulvae (Pennant) & + & & \\
\hline Macoma balthica L. & + & & \\
\hline Cerastoderma edule (L.) & + & & \\
\hline Mya arenaria L. & + & & \\
\hline Mytilus edulis $\mathrm{L}$. & & M & \\
\hline \multicolumn{4}{|l|}{ ANNELIDA } \\
\hline \multicolumn{4}{|l|}{ POLYCHAETA } \\
\hline \multicolumn{4}{|l|}{ Polynoidae } \\
\hline Harmothoe impar (Johnston) & & M, S & \\
\hline Harmothoe imbricata (L.) & & M & \\
\hline Lepidonotus squamatus (L.) & & $\mathrm{M}$ & \\
\hline \multicolumn{4}{|l|}{ Sigalonidae } \\
\hline Pholoe minuta (Fabricius) & & $\mathbf{S}$ & \\
\hline \multicolumn{4}{|l|}{ Phyllodocidae } \\
\hline Eteone longa (Fabricius) & + & & \\
\hline Anaitides mucosa (Oersted) & + & & \\
\hline Eumida sanguinea (Oersted) & + & & \\
\hline Eulalia viridis (L.) & + & $\mathrm{s}$ & \\
\hline \multicolumn{4}{|l|}{ Hesionidae } \\
\hline Kefersteinia cirrata (Keferstein) & + & & \\
\hline Microphthalmus aberrans (Webster \& Bened.) & + & & \\
\hline \multicolumn{4}{|l|}{ Syllidae } \\
\hline Autolytus spec. & & $\mathrm{S}, \mathrm{H}$ & \\
\hline \multicolumn{4}{|l|}{ Nereidae } \\
\hline Nereis diversicolor (O. F. Müller) & + & & \\
\hline Nereis succinea Frey \& Leuckart & + & & \\
\hline \multicolumn{4}{|l|}{ Orbinidae } \\
\hline Scoloplos armiger (O. F. Müller) & + & & \\
\hline \multicolumn{4}{|l|}{ Spionidae } \\
\hline Polydora quadrilobata Jacobi & + & & \\
\hline Polydora ciliata (Johnston) & + & $\mathrm{M}, \mathrm{S}, \mathrm{H}$ & \\
\hline Polydora Ligni Webster & & $\mathrm{H}$ & \\
\hline Pygospio elegans Claparede & + & & \\
\hline Malacoceros tetracerus (Schmarda) & + & & \\
\hline Malacoceros fuliginosus (Claparede) & + & & \\
\hline
\end{tabular}


Table 2 (continued)

\begin{tabular}{|c|c|c|c|}
\hline TAXA & Endofauna & Epifauna & Gues \\
\hline \multicolumn{4}{|l|}{ ANNELIDA } \\
\hline \multicolumn{4}{|l|}{ Cirratulidae } \\
\hline Tharyx marioni (Saint-Joseph) & + & & \\
\hline \multicolumn{4}{|l|}{ Capitellidae } \\
\hline Capitella capitata (Fabricius) & + & & \\
\hline Heteromastus filiformis (Claparede) & + & & \\
\hline \multicolumn{4}{|l|}{ Arenicolidae } \\
\hline \multirow{2}{*}{\multicolumn{4}{|c|}{ Ampharetidae }} \\
\hline & & & \\
\hline Ampharete finmarchica (M. Sars) & + & & \\
\hline \multicolumn{4}{|l|}{ Terebellidae } \\
\hline Neoamphitrite figulus (Dalyell) & & $\mathbf{S}$ & \\
\hline \multicolumn{4}{|l|}{ OLIGOCHAETA } \\
\hline Peloscolex benedeni (D'Udekem) & + & & \\
\hline Tubificoides pseudogaster (Dahl) & + & & \\
\hline Paranais litoralis (Müller) & + & & \\
\hline \multicolumn{4}{|l|}{ PANTOPODA } \\
\hline Nymphon grossipes (Fabricius) & & $\mathrm{H}$ & \\
\hline \multicolumn{4}{|l|}{ CRUSTACEA } \\
\hline Jaera albifrons Leach & & M & \\
\hline Idotea chelipes (Pallas) & & $\mathrm{M}$ & \\
\hline Gammarus locusta (L.) & & M & \\
\hline Semibalanus balanoides (L.) & & $\mathrm{M}$ & \\
\hline Balanus crenatus Breguiere & & M & \\
\hline Carcinus maenas (L.) & & & + \\
\hline Crangon crangon (L.) & & & + \\
\hline Pagurus bernhardus (L.) & & & + \\
\hline \multicolumn{4}{|l|}{ ECHINODERMATA } \\
\hline Asterias rubens L. & & M & \\
\hline
\end{tabular}

in the mussel bed. The decline in polychaete abundance and the corresponding increase in oligochaetes were significant $(P \leq 0.001)$. Molluscs and crustaceans, rare in the sandflat, comprised together $12-15 \%$ of the macrofauna at the edge and within the mussel bed. This distribution pattern corresponds with a significant increase in abundance between the sandflat and the mussel bed edge $\left(\mathrm{P} \leq 0.01\right.$ Mollusca; $\mathrm{P} \leq 0.001$ Crustacea, $_{1}$ Fig. 3).

Polychaete abundances along the transect could be separated into three distribution patterns:

(1) decreasing abundance from the sandflat towards the mussel bed of Tharyx marioni, Heteromastus filiformis, Scoloplos armiger, Pygospio elegans, Polydora quadrilobata;

(2) increasing abundance from the sandflat towards the mussel bed of Capitella capitata, Nereis diversicolor, Malacocerus tetracirrus; and

(3) a steady abundance at all stations of Eteone longa, Anaitides mucosa, Microphthalmus aberrans. 
Table 3. Macrofaunal species recorded along three stations of a transect. The total number of species from three sampling dates is given above. Mean species densities beneath $100 \mathrm{~cm}^{2}$ (standard deviations in parenthesis, $n=6$ ) and their significant differences between stations are given below (asterisks sign for significance level of U-test)

\begin{tabular}{|c|c|c|c|c|c|c|}
\hline \multirow[t]{2}{*}{ Taxon } & \multirow{2}{*}{$\begin{array}{l}\text { Sandflat } \\
\text { (s) }\end{array}$} & \multicolumn{2}{|c|}{ Mussel bed } & \multicolumn{3}{|c|}{ U-test } \\
\hline & & Edge (e) & Centre (c) & $s-e$ & $s-c$ & $e-c$ \\
\hline \multicolumn{7}{|l|}{ Total } \\
\hline Polychaeta & 16 & 12 & 13 & & & \\
\hline Molluscs & 4 & 6 & 5 & & & \\
\hline Crustacea & & 4 & 3 & & & \\
\hline Total benthos & 20 & 25 & 25 & & & \\
\hline \multicolumn{7}{|l|}{ Mean } \\
\hline Polychaeta & $8.0(1.6)$ & $6.7(1.5)$ & $5.2(1.6)$ & $\cdots$ & $\cdots *$ & $*$ \\
\hline Mollusca & $0.8(0.7)$ & $3.2(1.1)$ & $2.7(1.1)$ & $\cdots$ & $\cdots$ & n.s. \\
\hline Crustacea & & $0.7(0.8)$ & $1.2(0.8)$ & - & - & * \\
\hline Total benthos & $8.6(2.0)$ & $11.0(2.7)$ & $9.7(2.7)$ & $\cdots$ & n.s. & n.s. \\
\hline
\end{tabular}

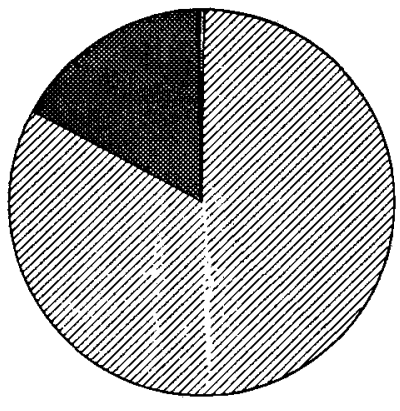

s a nd f l a t

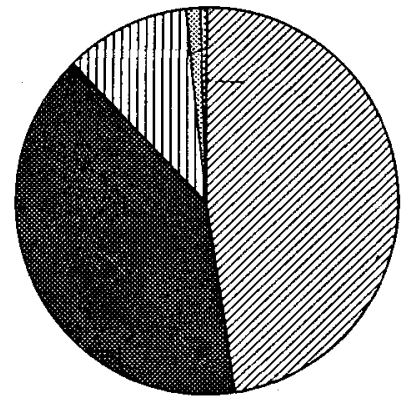

edge

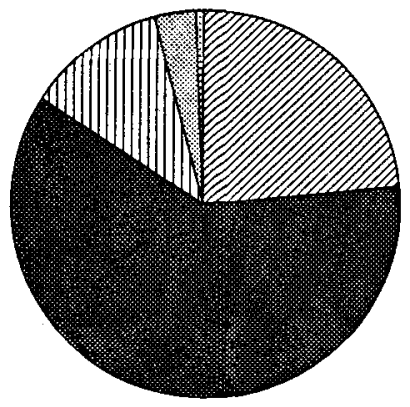

centre

mussel bed

$$
\begin{aligned}
\square & =\text { Polychaeta } \\
& =\text { Oligochaeta } \\
\text { WW } & =\text { Mollusca }
\end{aligned}
$$

$$
\begin{aligned}
& =\text { Crustacea } \\
& \text { = Nemertini }
\end{aligned}
$$

Fig. 2. Percentage of taxa on the total macrofaunal abundance along three stations of a transect, based on the individual sum of six samples per station and month. $360^{\circ}$ of the circle are equivalent to $100 \%$

The rank order of abundance of Polychaeta at the three stations varied with their feeding mode (Table 4). The surface filter feeding $T$. marioni was the most abundant in the sandflat station while subsurface deposit feeding capitellids ( $H$. filiformis and C. capitata) were the most common at the edge and centre of the mussel bed. $H$. filiformis had a high ranking in the mussel bed, although its abundance was low here compared to its abundance in the sandflat. 

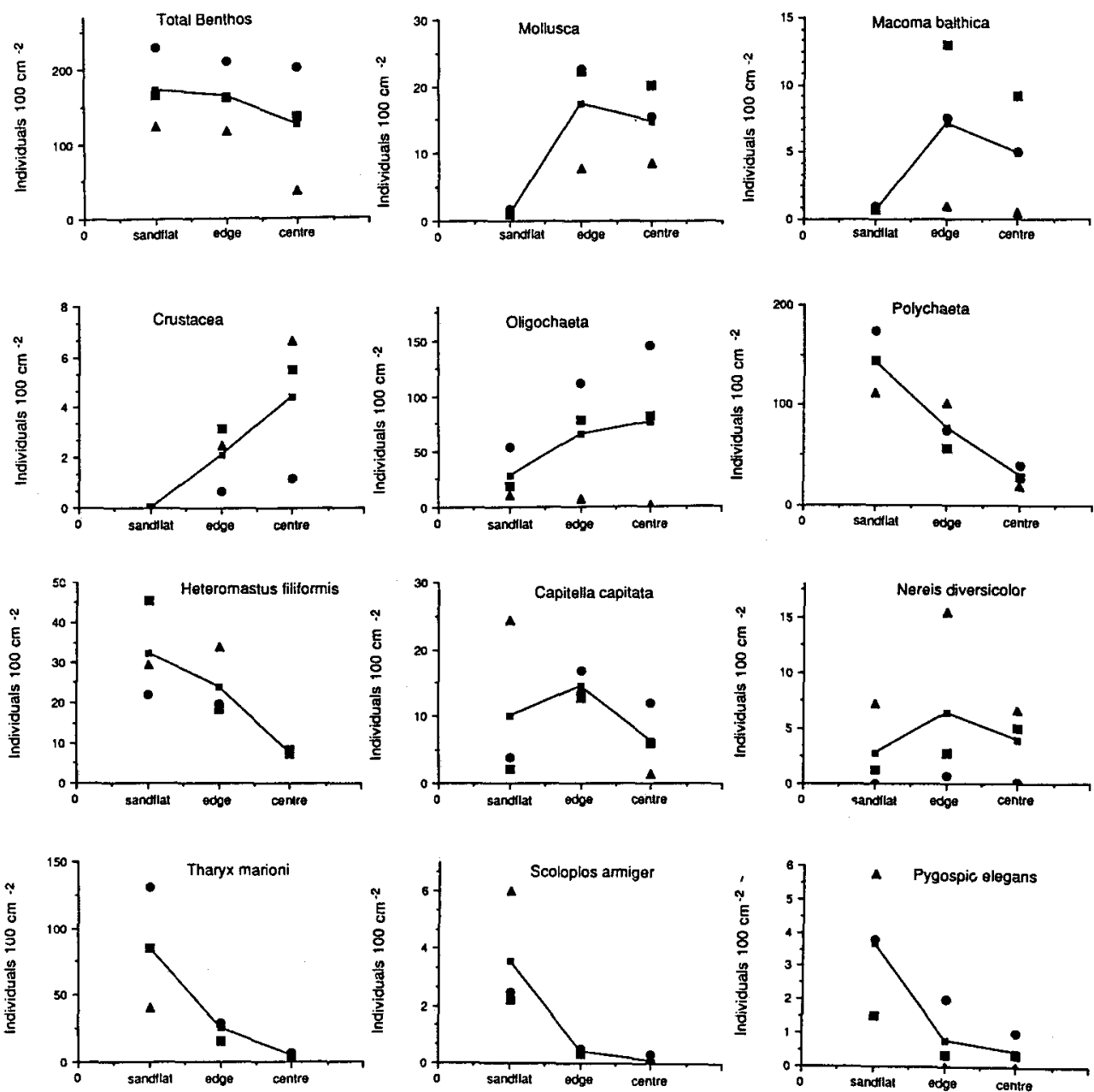

Fig. 3. Abundances of macrofauna along the transect from sandflat to mussel bed (edge and centre). Polychaete species with a mean abundance $>1$ are given. Mean abundances from three sampling occasions ( $\triangle$ September, $\backsim$ March, $\bullet$ May) and the mean abundance over all seasons (connected by lines) are given

No seasonal changes were detected in the general distribution pattern. An increase in total abundance in spring (Fig. 3) was found at all stations. Juvenile bivalves (Macoma balthica) settled in the mussel bed sites from March onward. The increase in oligochaete density between October and the coming spring sampling dates may have been due to an improved treatment of samples (separation of the upper layer). Seasonal differences in polychaete abundances were more pronounced in the sandflat and the edge of the mussel bed than in its centre (Fig. 3). Larvae of Tharyx marioni settled in the sandflat station in May, but did not occur in the mussel bed. The filter feeding Polydora quadrilobata established a population in the sandflat in spring. At the edge of the mussel 
Table 4. Rank-order of abundance of Polychaeta inhabiting three stations of a transect during September (IX), March (III) and May (V). The three top ranks are given with the first rank taking the largest symbol. In March and May two species with equal abundances shared the third rank in the sandflat. Feeding modes are according to Fauchald \& Jumars (1979)

\begin{tabular}{|c|c|c|c|c|c|c|c|c|c|c|}
\hline \multirow[t]{3}{*}{ Species } & \multirow{3}{*}{$\begin{array}{l}\text { Feeding } \\
\text { mode }\end{array}$} & \multirow{2}{*}{\multicolumn{3}{|c|}{ Sandflat }} & \multicolumn{6}{|c|}{ Mussel bed } \\
\hline & & & & & & Edg & & & Cent & \\
\hline & & IX & III & $\mathrm{V}$ & IX & III & $\mathrm{V}$ & IX & III & V \\
\hline Tharyx marioni & SMT & & & & & & & & & \\
\hline Heteromastus filiformis & $\mathrm{BMX}$ & & & & & & & & & \\
\hline Capitella capitata & $\mathrm{BMX}$ & $\bullet$ & - & - & & & - & & & \\
\hline Nereis diversicolor & & & & & - & & & & $\bullet$ & \\
\hline Scoloplos armiger & $\mathrm{BMC}$ & & $\bullet$ & & & & & & & \\
\hline Pygospio elegans & FSDT & & & - & & & & & & \\
\hline Anaitides mucosa & $\mathrm{CMX}$ & & & & & & & & & \\
\hline
\end{tabular}

bed, the abundance of $H$. filiformis declined from late summer to spring. Most of the polychaete species occurred in high densities in the late summer prior to population declines in the winter. The sampling date in March was the first after a severe winter which had covered the tidal bay with ice for several weeks. The scavenging Anaitides mucosa was the only polychaete found moving over the flats at this time of year, in response to an increased food supply and reproductive cyclicity (Hüttel, 1984).

In their vertical distribution, $80-90 \%$ of the individuals of all taxa lived in the top $2 \mathrm{~cm}$ of the substrate. This was the almost flocculent layer of mussel biodeposits. Below two centimeters, the mud was firm and anoxic. In the sandflat, $81 \%$ of the Polychaeta lived in the layer of $0-2 \mathrm{~cm}$ depth. In the mussel bed, $60 \%$ of the Polychaeta lived in that layer and $40 \%$ in $2-15 \mathrm{~cm}$ depth.

Comparing the occurrence of all macrobenthic species (QS) and their abundances (R) along the transect, the assemblages of the edge and the centre of the mussel bed were more similar to each other than to the sandflat (Table 5). The sandflat assemblage in turn was more closely related to that at the edge than to that in the centre of the mussel bed. A comparison of the polychaete community along the transect revealed a gradual decline in similarity from the sandflat to the mussel bed (Table 5). Similar species inhabited the sandflat and the edge station, but with different abundances. The macrofauna in the mussel bed and sandflat formed distinct communities (Table 6) and diversity was higher

Table 5. Comparison of macrofaunal assemblages at three stations of a transect. QS = Sørensen Index, $\mathrm{R}=$ Renkonen Index. The data are based on total findings on three sampling dates

\begin{tabular}{|lllllll|} 
& \multicolumn{2}{c}{ Sandflat/Edge } & \multicolumn{2}{c}{ Sandflat/Centre } & \multicolumn{2}{c|}{ Edge/Centre } \\
& QS & R & QS & R & QS & R \\
\hline Total benthos & 0.68 & 0.54 & 0.61 & 0.33 & 0.80 & 0.71 \\
Polychaeta & 0.86 & 0.68 & 0.76 & 0.46 & 0.80 & 0.74 \\
Mollusca & 0.55 & 0.59 & 0.44 & 0.42 & 0.83 & 0.78 \\
Crustacea & 0 & 0 & 0 & 0 & 0.86 & 0.62 \\
\hline
\end{tabular}


Table 6. Characterization of the macrofaunal assemblages at three transect stations, averaged from three sampling dates. $H=$ Shannon's index of diversity, $D=$ dominance index by Hurlbert (1971), $\mathrm{e}=$ eveness (Pielou, 1966), ds = species richness (Margalef, 1958)

\begin{tabular}{|lccc|}
\hline Index & Sandflat & & Mussel bed \\
& & Edge & Centre \\
\hline $\mathrm{H}=-\Sigma$ piln pi & 1.54 & 2.07 & 1.98 \\
$\mathrm{D}=1-\Sigma$ pi 2 & 0.69 & 0.82 & 0.79 \\
$\mathrm{e}=\mathrm{H} / \log \mathrm{S}$ & 1.31 & 1.59 & 1.56 \\
$\mathrm{ds}=\mathrm{S}-1$ /log $\mathrm{N}$ & 4.75 & 6.35 & 6.58 \\
\hline
\end{tabular}

in the mussel bed. The edge of the mussel bed can be described as an intermediate transition zone rather than an ecotone with enhanced numbers.

\section{Comparison between meiofaunal assemblages of mussel bed and sandflat}

The abundance of meiofauna was significantly lower in the mussel bed $(123 \pm 30$ individuals $10 \mathrm{~cm}^{-2}$ ) compared to the adjacent sandflat (199 \pm 40 individuals $10 \mathrm{~cm}^{-2}$ ) $(\mathrm{P} \leq 0.01)$ (Fig. 4). This trend was exhibited by all taxa except for the Copepoda. Plathelminthes comprised $0.2 \%$ of the meiofauna in the mussel bed and $1.8 \%$ in the sandflat. In another mussel bed of the Königshafen, $10.6 \%$ of the meiofauna consisted of Plathelminthes. The plathelminth assemblage of this mussel bed had been investigated in detail during 1982 and 1983 (Dittmann, 1984). Seasonal variation was low and a characterization of the assemblage is given in Table 7. Acoelous Plathelminthes accounted for $87 \%$ of the abundance. Their density resulted in an increased mean abundance compared to the plathelminth assemblage in a nearby sandflat (Reise, 1984) (Table 7). In the mussel bed, 32 species (out of 44 ) occurred, each with a density of less than $1 \%$ of the total abundance.

No spatial differences were detected for benthic meiofauna, but macroalgae and hydrozoan colonies of temporary pools were colonized by epiphytal plathelminth species (Pseudostomum quadrioculatum and Phonorhynchus helgolandicus) (Table 2). $11 \%$ of the plathelminth species were epibenthic.

The abundance and species composition of plathelminth feeding modes were well balanced in the sandflat (Table 7). In contrast, a few grazing species accounted for $90 \%$ of overall abundance in the mussel bed, and predatory species were rare. The meiobenthic plathelminth community in the mussel bed clearly differed from those of the ambient sediments.

\section{DISCUSSION}

\section{Mussel beds as habitat}

Aggregations of suspension-feeding blue mussels are common in the lower intertidal of the Wadden Sea, where they form bioherms of heterotrophic organisms (Reise, 1985). Beneath the mussel cover the sediment is muddy, rich in organic matter and often anoxic with high levels of $\mathrm{H}_{2} \mathrm{~S}$ (Dittmann, 1987; Verwey, 1952; Wohlenberg, 1937). Above the 

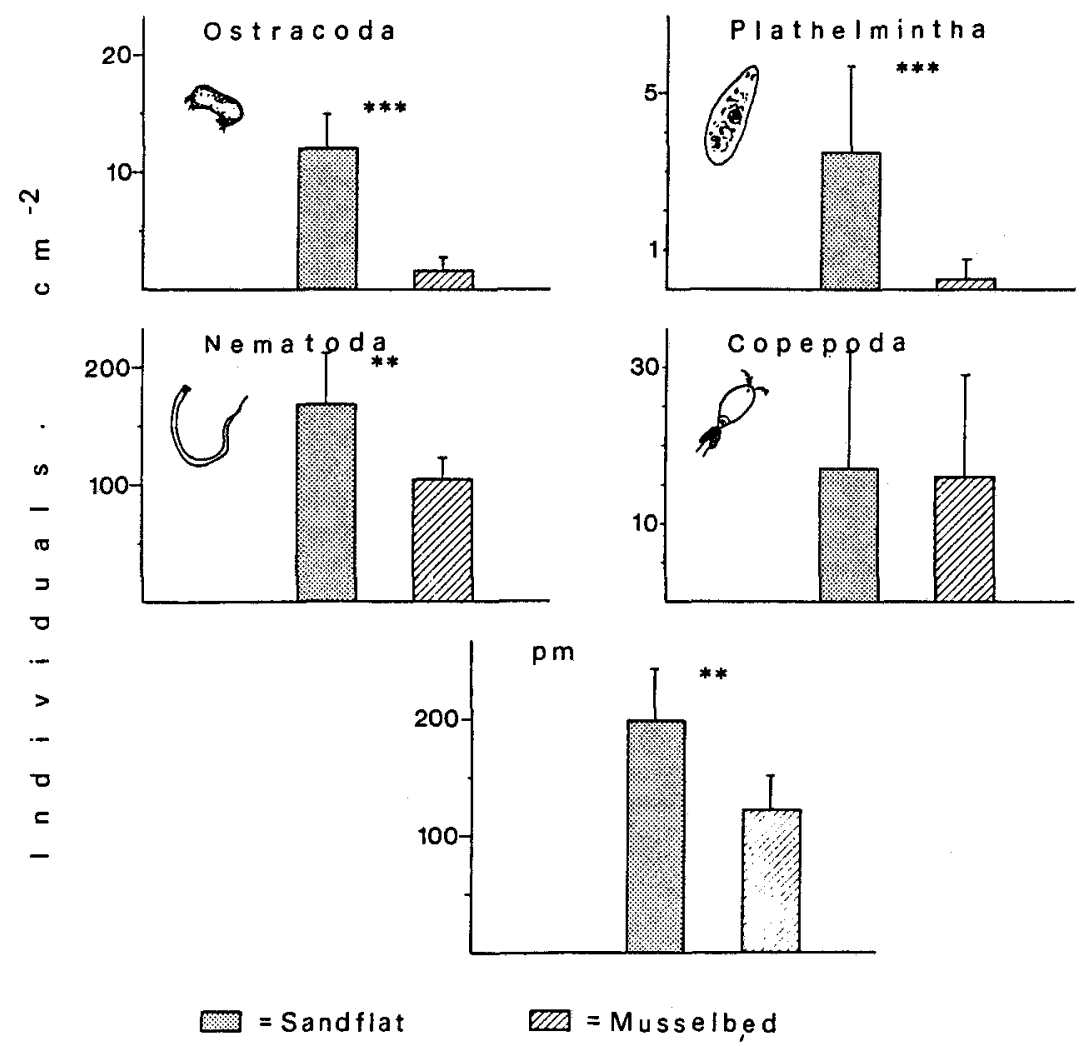

Fig. 4. Meiofauna abundance (individuals $1 \mathrm{~cm}^{-2}, 0-2 \mathrm{~cm}$ depth) at the sandflat and mussel bed station of a transect in September 1984. The height of the columns are mean values $(n=8)$ with standard deviations given as bars. Significant differences (U-Test) are indicated as ${ }^{*}=\mathrm{P} \leq 0.01$ and $* *=\mathrm{P} \leq 0.001$

surface, mussel shells provide novel substrata for settlement of hard bottom fauna. Such hard substrata do not exist in adjacent sandflats. Any evaluation of the fauna associated with a mussel bed should consider the microhabitats and ecological processes of the faunal components.

The edge station was a physiognomical part of the mussel bed and inhabited by the same epibenthic organisms as the centre. Sediment modifications by the mussels are not as severe at the edge as inside the mussel bed and the endobenthic communities changed more gradually with distance from the beds. Faunal similarities to either adjacent habitat were high at the edge. No species occurred exclusively at the edge of the mussel bed, nor was diversity higher. Thus the edge does not represent an ecotone.

\section{Infaunal distribution patterns}

The infauna beneath the mussel bed differed from the sandflat infauna in species composition, abundance patterns and trophic structure. Total species numbers and mean 
Table 7. Abundance and diversity of the Plathelminth assemblages in the upper layer $(0-1.5 \mathrm{~cm})$ of a natural mussel bed and a nearby sandflat investigated by Reise (1984). For indices see Table 6

\begin{tabular}{|lcc|}
\hline Plathelminth assemblage & Sandflat & Mussel bed \\
\hline Mean abundance $10 \mathrm{~cm}^{-2}$ & 111 & 160 \\
Number of species $10 \mathrm{~cm}^{-2}$ & 24 & 7 \\
Total number of species & 83 & 44 \\
Abundance of predators (\%) & 53 & 10 \\
Abundance of grazers (\%) & 42 & 90 \\
Predatory species (\%) & 65 & 74 \\
Grazing species (\%) & 35 & 26 \\
Most abundant species & Neoschizorhynchus & Archaphanostoma \\
& parvorostro & 0.08 \\
Biomass (g/m ${ }^{2}$ ) & 0.26 & 0.30 \\
Mean length of & & 0.71 \\
individuals (mm) & 1.06 & 0.24 \\
H & 3.35 & 0.43 \\
D & 0.95 & agile \\
e & 1.75 & \\
\hline
\end{tabular}

species densities of infaunal polychaetes and plathelminthes were lower in mussel beds. While most of the polychaete species were recorded from both sites, they occurred with varying densities along the transect and rare species were encountered less frequently in the mussel bed. The plathelminth assemblages in and outside of the mussel bed were composed of similar percentages of predatory and grazing species, but a single grazing species (Archaphanostoma agile) dominated in abundance in the mussel bed (Table 7).

Overall infaunal densities were highest in the sandflat station of the transect, whereas Commito (1987) recorded comparatively low infaunal densities outside of a mussel bed. This study does not support an enhancement of infauna coexisting with mussel beds, as proposed by Commito \& Boncavage (1989). The macrobenthic community in the mussel bed was dominated by deposit-feeding Oligochaeta (Fig. 2). This positive correlation between mussels and oligochaete density is well recorded (Commito, 1987; Commito \& Boncavage, 1989; Wohlenberg, 1937; Larsen, 1985). In all cited studies the abundance ranking of infaunal organisms was comparable, with crustaceans, bivalves and deposit-feeding polychaetes following the top-ranking oligochaetes.

Polychaeta from sediments beneath mussels $(H$. filiformis, $C$. capitata, $N$. diversicolor, $M$. tetracirrus, P. ligni) generally exhibit opportunistic life strategies (see Pearson \& Rosenberg, 1978 and therein). The occurrence of deposit-feeding and opportunistic infauna is also characteristic of fauna living in the organic rich mud accumulating underneath mussel cultures (Kaspar et al., 1985; Mattson \& Linden, 1983; Roman \& Perez, 1982; Rosenberg \& Loo, 1983). Within the polychaete assemblage $H$. filiformis ranked highest in the mussel bed, although its abundance there was significantly lower than in the sandflat. $H$. filiformis lives upside-down in the sediment and causes an almost homogenous vertical distribution pattern for polychaetes in the mussel bed. In the sandflat, biogenic structures by polychaetes and bivalves provide endobenthic microhabitats, accommodating further infauna (Reise, 1981, 1983 and 1985). This endobenthic 
habitat heterogeneity is missing beneath the mussel cover. Instead, mussel beds increase epibenthic heterogeneity.

\section{Epifaunal distribution patterns}

Almost a third of the species recorded were epibenthic on the mussel bed and half thereof were dwelling in microhabitats provided by epifauna or epiphytes on the mussels. Due to the epibenthic species, total species numbers and species diversity were higher in than outside of the mussel bed. Species occurring epibenthically on mussel beds belong to various trophic groups. Predatory crabs and polychaetes, grazing snails and amphipods as well as suspension-feeding barnacles and polychaetes were found on the mussels, in their algal cover, on sponges or in shell debris entangled in byssus threads. Tsuchiya \& Nishihira $(1985,1986)$ studied the community of experimental mussel patches on rocky substrates and found diverse feeding habits associated with them.

Epibenthic habitats are unpredictable, as seasonal, year to year and within mussel bed variability is high. During severe winters, epibenthos or the whole mussel layer can be dislodged when frozen to the ice. Over the summer, macroalgae (Fucus vesiculosus) cover parts of mussel beds (Wohlenberg, 1937). Hydrozoan colonies were only found in pools of mussel beds during summer months. Crabs (Pagurus bernhardus and Carcinus maenas) migrate from their sublittoral winter refuge into the tidal flats and find shelter under the algal cover or in pools of mussel beds during low tides. Aggregations of the snail Littorina littorea were often pronounced on mussel beds, but also found on ambient muddy sediments.

Year to year variations occurred during the 4-year study period, including increased settlement rates of juvenile mussels and barnacles after severe winters. High larval output after such winter conditions has been repeatedly observed for many intertidal organisms (Ziegelmeier, 1964, 1970; Beukema, 1979; Reise, 1985). Other year to year variations could not be explained. Abundant hydrozoan colonies, anthozoans and sponges were found in pools on mussel beds only in 1983 and 1984, but only rarely in the following years.

\section{Predation}

Predation pressure by epibenthic predators on a mussel bed varies with season and tidal cycles. Crabs, taking refuge on a mussel bed during low tide, can increase the predation pressure on the infauna. C. maenas preys on infauna (Scherer \& Reise, 1981) and $P$. bernhardus is an occasional predator on meiofauna (Gusky, 1987). Endobenthic predation by Nereis diversicolor on the oligochaete Peloscolex benedeni was found in field and laboratory experiments (Dittmann, 1987 and in prep.). Other endobenthic predators among the macro- and meiobenthos were rarely encountered in mussel beds.

\section{Trophic group response}

The trophic group response of infaunal organisms to mussel beds suggests that food supply and feeding mode play a role in determining distribution patterns. Even for the meiobenthic group of Plathelminthes the distribution patterns of feeding modes indicated a different food availability beneath the mussel layer. Low meiobenthos densities beneath mussels do not provide sufficient prey for predatory Plathelminthes. A higher 
abundance of grazing and bacteria-feeding Plathelminthes reflects this food availability (Dittmann, 1987; Kosfeld, 1989). Subsurface deposit feeding oligochaetes and polychaetes inhabited the sediment of the mussel bed, while surface filter-feeders were dwelling in the sandflat. At the edge of the mussel bed both feeding modes were common.

The finding of this study that suspension-feeding mussels promote the establishment of a deposit-feeding infauna, is not in agreement with the trophic group amensalisms proposed by Rhoads \& Young (1970). Already Posey (1986) and Thrush (1988), finding the exclusion of the same feeding modes, reject the applicability of trophic group amensalism. Trophic group amensalism means that one trophic group (deposit-feeders, inhibitors) exclude another trophic group and epifaunal sessiles (suspension-feeders, amensals). In mussel beds, suspension-feeders (inhibitors) exclude other suspensionfeeders (amensals), but facilitate the occurrence of another trophic group (depositfeeders) and of epifauna with a wide range of feeding types. I propose to call this interaction trophic group amelioration as an attribute of structural heterogeneity of epibenthic bioherms. It is an extension of the promotive process of sediment amelioration by endobenthos (Reise, 1985), Here, epibenthic macrofauna is the promotor and affects associated species by the combination of accomodation, fertilization and hydrodynamic properties. Other examples for trophic group amelioration are mussels on rock surface (Tsuchiya \& Nishihira, 1986) and reefs by sabellid polychaetes in the subtidal Wadden Sea (Riesen \& Reise, 1982; Hagmeier \& Kändler, 1927).

\section{Settlement and recruitment}

Differential settlement within and outside of the mussel bed caused some of the differences in abundances reported in this study. Molluscs ( $M$. balthica) settled preferentially in the mussel bed while juvenile polychaetes ( $T$. marioni, P. quadrilobata) established populations in the sandflats. These recruitment patterns can be explained by larval predation of the mussels, larval response to settlement cues, or the suitability of the substrate. The enhanced settlement of $M$. balthica in the mussel bed could have been induced by the suitability of the substrate for demands of early settlement (Beukema \& deVlas, 1989). Functional group hypotheses use predation on larvae as one aspect for the mutual exclusion of feeding modes in soft bottom communities (Hunt et al., 1987; Rhoads \& Young, 1970; Scheltema, 1974; Woodin, 1976). Woodin (1976) hypothesized negative effects of suspension-feeding bivalves on the recruitment of infaunal species. Larvae, who pass the mussels alive, have little chance of surviving in the mussel biodeposits (Mileikovsky, 1974). Commito (1987) observed that infaunal organisms maintaining high densities in mussel beds have benthic development stages and rejects Woodin's hypothesis that no dense infauna should develop with dense suspension-feeders. Commito \& Boncavage (1989) proposed to limit her hypothesis to predation on organisms with pelagic development stages. This is supported by this study, as Oligochaeta with benthic development were the only abundant infauna beneath mussels.

Yet, the unsuccessful recruitment of polychaetes may be due to larval predation by the mussels. None of the polychaetes attained high infaunal densities beneath the suspension-feeding mussels, apart from $C$. capitata early in the year. While the sulphidecontaining sediment has a negative effect on settlement of capitellid larvae (Dubilier, 
1988), they avoid predation by the mussels with benthic dispersal (Grassle \& Grassle, 1974). This study confirms both Woodin's hypothesis and Commito \& Boncavage's proposed addition to it. The suspension-feeding mussels preyed upon pelagic polychaete larvae which could not attain high densities, and only infauna with benthic development successfully recruited and established populations in the mussel bed.

Mussel beds are a heterogeneous habitat in the intertidal, characterized by a species-rich fauna with high diversity, differing from ambient sandflat communities in dominance structures and frequency of feeding types. An amensalistic relationship with endobenthic organisms contrasts the amelioration for epibenthos. A variety of cooccurring functional groups adds to the framework of relationships and interactions structuring the faunal assemblage of mussel beds.

Acknowledgements. I thank Prof. Dr. K. Reise and Prof. Dr. P. Ax for interest and discussion in my work. The hospitality and friendship at the Wadden Sea Station of the BAH are deeply acknowledged. Lyndon DeVantier improved the English. The study was supported in part by a grant (Project Nr. Re 425/5) from the Deutsche Forschungsgemeinschaft (DFG), and later on by a grant of the Graduiertenförderung.

\section{LITERATURE CITED}

Armonies, W. \& Hellwig, M., 1986. Quantitative extraction of living meiofauna from marine and brackish muddy sediments. - Mar. Ecol. Prog. Ser. 29, 37-43.

Asmus, $H ., 1987$. Secondary production of an intertidal mussel bed community related to its storage and turnover compartments. - Mar. Ecol. Prog. Ser. 39, 251-266.

Beukema, J. J., 1976. Biomass and species richness of the macrobenthic animals living on the tidal flats of the Dutch Wadden Sea. - Neth. J. Sea Res. 10, 236-261.

Beukema, J. J., 1979. Biomass and species richness of the macrobenthic animals living on a tidal flat area in the Dutch Wadden Sea: effects of a severe winter. - Neth. J. Sea Res. 13, 203-223.

Beukema, J. J. \& Vlas, J. de, 1989. Tidal-current transport of thread-drifting postlarval juveniles of the bivalve Macoma balthica from the Wadden Sea to the North Sea. - Mar. Ecol. Prog. Ser. 52, 193-200.

Brenchley, G. A., 1982. Mechanisms of spatial competition in marine soft-bottom communities. J. exp. mar. Biol. Ecol. 60, 17-33.

Commito, J. A., 1987. Adult-larval interactions: predictions, mussels and cocoons. - Estuar. coast. Shelf Sci. 25, 599-606.

Commito, J. A. \& Boncavage, E. M., 1989. Suspension-feeders and coexisting infauna: an enhancement counterexample. - J. exp. mar. Biol. Ecol. 125, 33-42.

Dittmann, S., 1984. Die Turbellarienfauna der Schlicksedimente im Königshafen der Nordseeinsel Sylt. Dipl.-Arb., Univ. Göttingen, 93 pp.

Dittmann, S., 1987. Die Bedeutung der Biodeposite für die Benthosgemeinschaft der Wattsedimente. Unter besonderer Berücksichtigung der Miesmuschel Mytilus edulis L. Diss., Univ. Göttingen, $182 \mathrm{pp}$.

Dittmann, S. \& Reise, K., 1985. Assemblage of free-living Plathelminthes on an intertidal mud flat in the North Sea. - Microfauna mar. 2, 95-115.

Dubilier, N., 1988. $\mathrm{H}_{2} \mathrm{~S}-$ a settlement cue or a toxic substance for Capitella sp. I larvae? - Biol. Bull. mar. biol. Lab., Woods Hole 174, 30-38.

Fauchald, K. \& Jumars, P. A., 1979. The diet of worms: a study on polychaete feeding guilds. Oceanogr. mar. Biol. 17, 193-284.

Gee, J. M., Warwick, R. M., Schaaning, M., Berge, J. A. \& Ambrose, W. G., 1985. Effects of organic enrichment on meiofaunal abundance and community structure in sublittoral soft sediments. J. exp. mar. Biol. Ecol. 91, 247-262.

Grassle, J. E. \& Grassle, J. P., 1974. Opportunistic life histories and genetic systems in marine benthic polychaetes. - J. mar. Res. 32, 254-289. 
Gusky, M., 1987. Populationsstrukturen und Beutespektrum der Einsiedlerkrebse (Pagurus bernhardus) im Eulittoral und Sublittoral des Wattenmeeres. Dipl.-Arb., Univ. Göttingen, 89 pp.

Hagmeier, A. \& Kändler, R., 1927. Neue Untersuchungen im nordfriesischen Wattenmeer und auf den fiskalischen Austernbänken. - Wiss. Meeresunters. (Abt. Helgoland) 16, 1-90.

Hunt, J. H., Ambrose, W. G. \& Peterson, C. H., 1987. Effects of the gastropod, Ilyanassa obsoleta (Say), and the bivalve, Mercenaria mercenaria (L.), on larval settlement and juvenile recruitment of infauna. - J. exp. mar. Biol. Ecol. 108, 229-240.

Hurlbert, S. H., 1971. The non-concept of species diversity: a critique and alternative parameters. Ecology 52, 577-586.

Hüttel, M., 1984. Zur Ökologie aasfressender Wattbewohner. Untersuchungen an Carcinus maenas und Anaitides maculata. Dipl.-Arb., Univ. Kiel, 82 pp.

Kaspar, M. F., Gillespie, P. A., Boyer, I. C. \& Mackenzie, M., 1985. Effects of mussel aquaculture on the nitrogen cycle and benthic communities in Kenepuru Sound, Marborough Sounds, New Zealand. - Mar. Biol. 85, 127-136.

Kosfeld, C., 1989. Mikrobieller Abbau von Faeces der Miesmuschel (Mytilus edulis L.). Diss., Univ. Kiel, $131 \mathrm{pp}$.

Larsen, P. F., 1985. The benthic macrofauna associated with the oyster reefs of the James River Estuary, Virginia, USA. - Int. Revue ges. Hydrobiol. 70, 797-814.

Margalef, R., 1958. Information theory in ecology. - Gen. Syst. 3, 36-71.

Mattson, J. \& Linden, O., 1983. Benthic macrofauna succession under mussels, Mytilus edulis L. (Bivalvia) cultured on hanging long-lines. - Sarsia 68, 97-102.

Mileikovsky, S. A., 1974. On predation of pelagic larvae and early juveniles of marine bottom invertebrates by adult benthic invertebrates and their passing alive through their predators. Mar. Biol. 26, 303-311.

Pearson, T. H. \& Rosenberg, R., 1978. Macrobenthic succession in relation to organic enrichment and pollution of the marine environment. - Oceanogr. mar. Biol. 16, 229-311.

Pielou, E. C., 1966. The measurement of diversity in different types of biological collections. J. theor. Biol. 13, 131-144.

Posey, M. H., 1986. Changes in the benthic community associated with dense beds of a burrowing deposit-feeder, Callianassa californiensis, - Mar. Ecol. Prog. Ser. 31, 15-22.

Reise, K., 1981. High abundance of small zoobenthos around biogenic structures in tidal sediments of the Wadden Sea. - Helgoländer Meeresunters. 34, 413-425.

Reise, K., 1983. Biotic enrichment of intertidal sediments by experimental aggregates of the depositfeeding bivalve Macoma balthica. - Mar. Ecol. Prog. Ser. 12, 229-236.

Reise, K., 1984. Free-living Plathelminthes (Turbellaria) of a marine sand flat: an ecological study. Microfauna mar. 1, 1-62.

Reise, K., 1985. Tidal flat ecology. Springer, Berlin, $191 \mathrm{pp}$.

Renkonen, O., 1938. Statistisch-ökologische Untersuchungen über die terrestrische Käferwelt der finnischen Bruchmoore. - Annls zool. Soc. zool.-bot. fenn. 6, 1-231.

Rhoads, D. C. \& Young, D. K., 1970. The influence of deposit-feeding organisms on sediment stability and community trophic structure. - J. mar. Res. 28, 150-178.

Riesen, W. \& Reise, K., 1982. Macrobenthos of the subtidal Wadden Sea: revisited after 55 years. Helgoländer Meeresunters. 35, 409-423.

Roman, G. \& Perez, A., 1982. Estudio del mejillon y de su epifauna en los cultivos flotantes de los Rio de Arosa. IV. Evolucion de la communidad. - Boln Inst. esp. Oceanogr. 7, 279-296.

Rosenberg, R. \& Loo, L.-O., 1983. Energy-flow in a Mytilus edulis culture in western Sweden. Aquaculture 35, 151-161.

Sachs, L., 1984. Angewandte Statistik. Springer, Berlin, $552 \mathrm{pp}$.

Scheltema, R. S., 1974. Biological interactions determining larval settlement of marine invertebrates. - Thalassia jugosl. 10, 263-296.

Scherer, B. \& Reise, K., 1981. Significant predation on micro- and macrobenthos by the crab Carcinus maenas L. in the Wadden Sea. - Kieler Meeresforsch. (Sonderh.) 5, 490-500.

Sørensen, T. A., 1948. A method of establishing groups of equal amplitude in plant sociology based on similarity of species content, and its application to analyses of the vegetation on Danish commons. - Biol. Skr. 5, 1-34. 
Suchanek, T. H., 1980. Diversity in natural and artificial mussel bed communities of Mytilus californianus. - Am. Zool. 20, 807.

Tenore, K. R. \& Gonzales, N., 1976. Food chain patterns in the Ria de Arosa, Spain: an area of intense mussel aquaculture. In: Proceedings of the 10th European symposium on marine biology. Ed. by G. Persoone \& E. Jaspers. Wetteren, Universa Press, 2, 601-619.

Thrush, S. F., 1988. The comparison of marobenthic recolonization patterns near and away from crab burrows on a sublittoral sandflat. - J. mar. Res. 46, 669-681.

Tsuchiya, M. \& Nishihira, M., 1985. Islands of Mytilus as a habitat for small intertidal animals: effect of island size on community structure. - Mar. Ecol. Prog. Ser. 25, 71-81.

Tsuchiya, M. \& Nishihira, M., 1986. Islands of Mytilus edulis as a habitat for small intertidal animals: effect of Mytilus age structure on the species composition of the associated fauna and community organization. - Mar. Ecol. Prog. Ser. 31, 171-178.

Verwey, J., 1952. On the ecology and distribution of cockle and mussel in the Dutch Wadden Sea, their role in sedimentation and the source of their food supply. - Archs neerl. Zool. 10, 171-239.

Wohlenberg, E., 1937. Die Wattenmeer-Lebensgemeinschaft im Königshafen von Sylt. - Helgoländer wiss. Meeresunters. 1, 1-92.

Woodin, S. A., 1976. Adult-larval interactions in dense infaunal assemblages: patterns of abundance. - J. mar. Res. 34, 25-41.

Ziegelmeier, E., 1964. Einwirkungen des kalten Winters 1962/63 auf das Makrobenthos im Ostteil der Deutschen Bucht. - Helgoländer wiss. Meeresunters. 10, 276-282.

Ziegelmeier, E., 1970. Über Massenvorkommen verschiedener makrobenthaler Wirbelloser während der Wiederbesiedlungsphase nach Schädigung durch "katastrophale" Umwelteinflüsse. - Helgoländer wiss. Meeresunters. 21, 9-20. 